\section{Gibberellic Acid Slows Postharvest Degreening of 'Oroblanco' Citrus Fruits}

\author{
Ron Porat ${ }^{1}$ \\ Department of Postharvest Science of Fresh Produce, ARO, The Volcani \\ Center, Bet Dagan 50250, Israel
}

\section{Xuqiao Feng, Moshe Huberman, David Galili, Raphael Goren, and Eliezer E. Goldschmidt}

The Kennedy-Leigh Centre for Horticultural Research, Institute for Plant Sciences and Genetics, Faculty of Agricultural, Food, and Environmental Quality Sciences, The Hebrew University of Jerusalem, Rehovot 76100, Israel

Additional index words. ethylene, 1-methylcyclopropene, quarantine

\begin{abstract}
Oroblanco' is an early-maturing pummelo-grapefruit hybrid (Citrus grandis Osbeck $x$ C. paradisi Macf.). The fruit are usually picked and marketed while the peel color is still green; however, in some cases they can lose this green color during postharvest shipping and storage, which diminishes their commercial value. The effects of storage temperatures, gibberellic acid (GA), ethylene, and 1-methylcyclopropene (1-MCP) on the degreening of 'Oroblanco' fruit were examined. Storage temperature was critical for retaining fruit color: at $2{ }^{\circ} \mathrm{C}$ the fruit remained green for a period up to 5 weeks, whereas at storage temperatures of 6,12 , and $20^{\circ} \mathrm{C}$ there was a progressive increase in the rate of degreening. Applications of GA, either as preharvest sprays or as postharvest dip treatments, effectively retained the green fruit color. Ethylene exposures up to $100 \mu L^{\prime} \cdot L^{-1}$ for 3 days had only a slight effect on fruit degreening, and 1-MCP treatments up to 200 $n L \cdot L^{-1}$ for 16 hours had no effect at all. The slight influence of ethylene and the ineffectiveness of 1-MCP on fruit color change can not be attributed to difficulties in their application, since in the same experiments ethylene markedly induced peduncle abscission, and 1-MCP effectively inhibited this ethylene effect. Accordingly, ethylene had only a relatively small effect on the induction of chlorophyllase enzyme activity in green 'Oroblanco' peel tissue.
\end{abstract}

'Oroblanco' is a triploid pummelo-grapefruit hybrid that was generated in Riverside, Calif., by a cross between an acidless pummelo (Citrus grandis Osbeck) and a tetraploid grapefruit (Citrus paradisi Macf.) (Soost and Cameron, 1981). The general characteristics of the fruit are similar to those of 'Marsh' seedless white grapefruit, despite the fact that they have a higher percentage of total soluble solids (TSS) and a lower acid content. 'Oroblanco' also lacks the typical bitterness of grapefruit and instead has a special, sweet aroma that is more similar to pummelo (Soost and Cameron, 1981).

'Oroblanco' is an early-maturing cultivar,

Received for publication 30 Aug. 2000. Accepted for publication $26 \mathrm{Jan}$. 2001. Contribution from the Agricultural Research Organization, the Volcani Center, Bet Dagan, Israel. No. 420/00, 2000 series. This research was partially funded by the U.S.Israel Binational Agricultural Research and Development (BARD) Fund No. US-2786-96R given to R.G. We thank Dr. M. Zarchi for her assistance with the statistical analysis. The cost of publishing this paper was defrayed in part by the payment of page charges. Under postal regulations, this paper therefore must be hereby marked advertisement solely to indicate this fact.

${ }^{1}$ To whom reprint requests should be addressed. E-mail address: rporat@ volcani.agri.gov.il which, according to its internal characteristics, is ready for eating in October (Soost and Cameron, 1981; Traiber et al., 1984). Commercially, the fruit are usually picked between October and November and are exported from Israel, mainly to Japan, when the peel is still green. Unfortunately, in some cases the fruit color changes during postharvest shipping and storage, and as a result the fruit loses some of its commercial value.

Several preharvest and postharvest factors may affect the degreening of 'Oroblanco' fruit. Storage temperature is a major factor determining the rate of postharvest deterioration of commodities (Kader, 1992). In citrus, specifically, storage temperature is an important consideration in commercial fruit degreening (Grierson et al., 1986). Generally, increasing the temperature to $30^{\circ} \mathrm{C}$ enhances chlorophyll degradation, whereas somewhat lower temperatures of 23 to $25^{\circ} \mathrm{C}$ are optimal for carotenoid biosynthesis (Ahrens and Barmore, 1986; Jahn et al., 1973; Stewart and Wheaton, 1972). Thus, for 'Oroblanco' low storage temperatures should delay peel deterioration and chlorophyll loss while higher temperatures should enhance degreening.

Gibberellic acid (GA) is commonly used to delay senescence and loss of chlorophyll in various citrus fruits (Coggins et al., 1992; ElOtmani et al., 1990; Garcia-Luis et al., 1992;
Greenberg et al., 1992; McDonald et al., 1997). In fact, GA sprays in the orchard are currently being used as a horticultural practice to prolong the harvest season and maintain the green color of 'Oroblanco' fruit (Greenberg et al., 1986).

Citrus fruits are nonclimacteric, and the precise role of endogenous ethylene in the regulation of fruit maturation and peel color change is not yet clearly understood. Nevertheless, exogenous ethylene is commonly being used for commercial degreening of citrus fruit (Grierson et al., 1986), and it is believed that the chemical acts by increasing chlorophyllase activity (Trebitsh et al., 1993). Studies with several ethylene inhibitors, such as 2,5-norbornadiene (NBD), silver nitrate, and 1-methylcyclopropene (1-MCP), have shown that by blocking the response of the fruits to endogenous ethylene it is possible to inhibit natural degreening in 'Shamouti' oranges (Goldschmidt et al., 1993; Porat et al., 1999).

In the current study, we have evaluated the effects on the postharvest degreening of 'Oroblanco' citrus fruit of different storage temperatures, preharvest and postharvest GA applications, and exposure of the fruit to various concentrations of ethylene and 1-MCP.

\section{Materials and Methods}

Effect of temperature and length of storage. 'Oroblanco' fruit were harvested in October from local orchards, and their external color was evaluated immediately. Sixty fruit from each of three locations (replications) were selected, and a circle was drawn on the surface of each with a black marker. The hue angle of the peel within this circle was measured with a Minolta chroma meter (model CR-200; Minolta, Ramsey, N.J.), as described elsewhere (McGuire, 1992). The hue angle of these fruit at harvest was $\approx 122^{\circ}$; a hue angle of $120^{\circ}$ represents green color, whereas $90^{\circ}$ represents yellow. From each replicate 15 fruit were randomly selected for storage at 2, 6, 12, or $20^{\circ} \mathrm{C}$ for 5 weeks at $\approx 90 \%$ relative humidity. Hue angle at the marked location was subsequently measured weekly.

Effect of GA applications and 1-MCP and ethylene treatments. Prior to the October harvest, certain trees were sprayed twice during the months of August and September with 10 $\mathrm{mg} \cdot \mathrm{L}^{-1}$ of GA (Machteshim, Israel) containing $0.05 \%$ Triton-B (Agan, Israel) as a surfactant. The fruit from some of these trees were also treated with GA postharvest by dipping for 20 $\mathrm{s}$ in $100 \mathrm{mg} \cdot \mathrm{L}^{-1}$ of GA in tap water with $0.15 \%$ BB5 (CTS, Israel) as a surfactant in a combination treatment. A third treatment received only the postharvest dip. Along with an untreated control, all fruit were stored for 5 weeks at $20^{\circ} \mathrm{C}$, and hue angle was measured weekly at a marked location. Each treatment consisted of 15 fruit replicated three times.

In a similar test, fruit were placed in sealed $30-\mathrm{L}$ plastic tanks and treated for $16 \mathrm{~h}$ with 1 $\mathrm{MCP}$ at 20,100 , or $200 \mathrm{~nL} \cdot \mathrm{L}^{-1}$ or for $3 \mathrm{~d}$ with ethylene at concentrations of 10,40 , or 100 $\mu \mathrm{L} \cdot \mathrm{L}^{-1}$. In both cases the exposure to the gas was carried out at $21^{\circ} \mathrm{C}$. The concentrated 
stock of $1-\mathrm{MCP}\left(3000 \mu \mathrm{L} \cdot \mathrm{L}^{-1}\right)$ was a gift from Prof. E.C. Sisler (Univ. of North Carolina). The required final concentrations of 1-MCP and ethylene were obtained by injecting appropriate amounts of the gases into the experimental tanks. Along with an untreated control, all fruit were stored for 5 weeks at $20^{\circ} \mathrm{C}$, and hue angle was measured weekly at a marked location. Each treatment consisted of 15 fruit replicated three times.

To validate the efficacy of $1-\mathrm{MCP}$ and ethylene, some fruit that had been treated as above with 1-MCP $\left(20,100\right.$, or $\left.200 \mathrm{~nL} \cdot \mathrm{L}^{-1}\right)$ for $16 \mathrm{~h}$ were subsequently kept for $3 \mathrm{~d}$ in air or exposed to $10 \mu \mathrm{L} \cdot \mathrm{L}^{-1}$ of ethylene over that time period. The abscission of the fruits' peduncle was subsequently measured after 4 weeks of storage at $20^{\circ} \mathrm{C}$. Fifteen fruit per treatment were tested from each of three replications.

Chlorophyllase activity. Extraction of the chlorophyllase enzyme and its activity were assayed as described in detail by Trebitsh et al. (1993). Briefly, the flavedo from 10 green fruit (hue angle of peel $=118$ to $122^{\circ}$ ) or yellow fruit (hue angle of peel $=100$ to $105^{\circ}$ ) was removed and homogenized in $50 \mathrm{~mm}$ Tris$\mathrm{HCl}\left(\mathrm{pH}\right.$ 8.0) and centrifuged at $12,000 g_{\mathrm{n}}$ for $10 \mathrm{~min}$. The pellet was homogenized in acetone at $-15{ }^{\circ} \mathrm{C}$ for the preparation of an acetone powder. For the determination of chlorophyllase activity, $20 \mathrm{mg}$ of acetone powder were stirred for $30 \mathrm{~min}$ at $37^{\circ} \mathrm{C}$ with $20 \mathrm{~mL}$ of a solution of $5 \mathrm{~mm}$ potassium phosphate $(\mathrm{pH}$ 7.0), $50 \mathrm{~mm} \mathrm{KCl}$, and $0.24 \%$ Triton X-100. The extract was filtered through glass wool and centrifuged again at 12,000 gn for $10 \mathrm{~min}$, and the supernatant was collected. To measure chlorophyllase activity, $0.2-\mathrm{mL}$ aliquots of the enzyme were incubated at $37^{\circ} \mathrm{C}$ for up to 60 min in $2.8 \mathrm{~mL}$ of a solution of $100 \mathrm{~mm}$ sodium phosphate ( $\mathrm{pH} 7.0$ ), $0.24 \%$ Triton $\mathrm{X}-100$, and $0.2 \mu \mathrm{mol}$ of chlorophyll-a dissolved in $100 \%$ acetone. The reaction was stopped by transferring $0.5 \mathrm{~mL}$ of the reaction mixture to centrifuge tubes containing acetone/hexane $/ 10 \mathrm{~mm}$ $\mathrm{KOH}$, at ratios of 4:6:1 (by volume), and after phase separation, chlorophyllide-a in the acetone phase was determined spectrophotometrically at $667 \mathrm{~nm}$. The experiment was repeated three times.

Fruit quality after commercial quarantine and long-term storage. A second type of storage experiment compared a short, cold method that simulates a commercial quarantine treatment against the Mediterranean fruit fly [Ceratitis capitata (Wiedemann)] with long-term storage. Untreated control fruit were compared with those sprayed as above with GA in the orchard and also with fruit sprayed with GA in the orchard and then after harvest exposed to $200 \mathrm{~nL} \cdot \mathrm{L}^{-1}$ of $1-\mathrm{MCP}$ for $16 \mathrm{~h}$. For the short quarantine storage, fruit were held for 3 weeks at $2{ }^{\circ} \mathrm{C}$ followed by 1 week at $12^{\circ} \mathrm{C}$ to simulate commercial treatment; long-term storage lasted 11 weeks at $12{ }^{\circ} \mathrm{C}$. Following these storage regimes, the fruit were transferred to market conditions at $20^{\circ} \mathrm{C}$ prior to evaluation. Each of four replications consisted of 25 fruit per treatment. At the end of storage, hue angle (initially averaging $121.3^{\circ}$ ) was reevaluated. The percentage of total soluble solids (TSS) in the fruit juice was determined with a refractometer, and the percentage of acidity was measured by titration to $\mathrm{pH} 8.3$ with $0.1 \mathrm{~N} \mathrm{NaOH}$. Fruit were weighed before and after storage to assess weight loss, and the percentages of fruit that decayed or were injured by the chill temperatures were recorded at the end of each storage period.

Statistical analysis. Student-NewmanKeuls one-way analysis of variance (ANOVA) tests on ranks were performed using the SigmaStat statistical software (Jandel Scientific Software, San Rafael, Calif.). In addition, regression analysis according to the General Linear Model(GLM) procedure was performed using the SAS statistical analysis programs (SAS Institute, Cary, N.C.).

\section{Results}

Effect of storage temperature on fruit degreening. Following storage at $2{ }^{\circ} \mathrm{C}$, there was only a very slight change in the color of 'Oroblanco' fruit, whereas at 6,12 , and $20^{\circ} \mathrm{C}$, there was a progressive increase in the rate of degreening (Fig. 1). At $20{ }^{\circ} \mathrm{C}$, the fruit remained green during the first 2 weeks of storage but then began to change color very rapidly. A regression analysis of fruit color across time for each storage temperature showed that storage at $2{ }^{\circ} \mathrm{C}$ was significantly different from all of the other storage temperatures at $P$ $<0.01$. Storage at 6 and $12{ }^{\circ} \mathrm{C}$ was also significantly different from storage at $20^{\circ} \mathrm{C}$ at the same level of significance. There was no significant difference between storage temperatures of 6 and $12{ }^{\circ} \mathrm{C}$.

Effect of GA applications on fruit degreening. Both preharvest and postharvest applications of GA significantly retained the green color of 'Oroblanco' fruit and markedly reduced the rate of degreening as compared to untreated fruit (Fig. 2). A regression analysis of fruit color across time for each treatment has shown that the various preharvest, postharvest, and combined preharvest and postharvest GA application treatments were all significantly different from the untreated con-

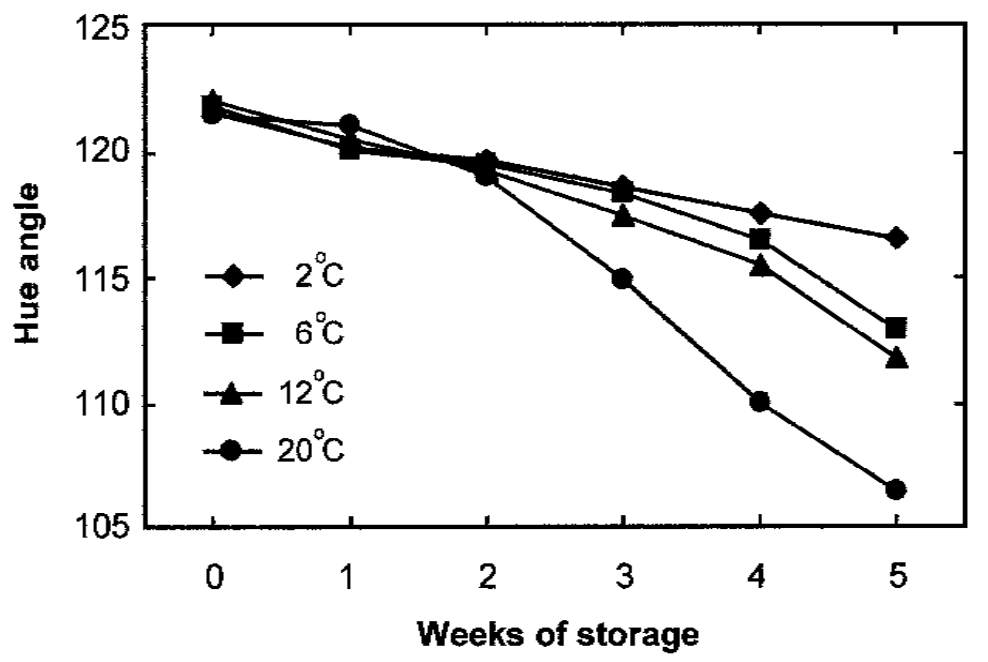

Fig. 1. Effect of storage temperatures on the degreening of 'Oroblanco' fruit. Fruit were stored for 5 weeks at $2,6,12$, and $20^{\circ} \mathrm{C}$. Data are means for 45 fruits from three separate experiments. Green $=120^{\circ}$, yellow $=90^{\circ}$.

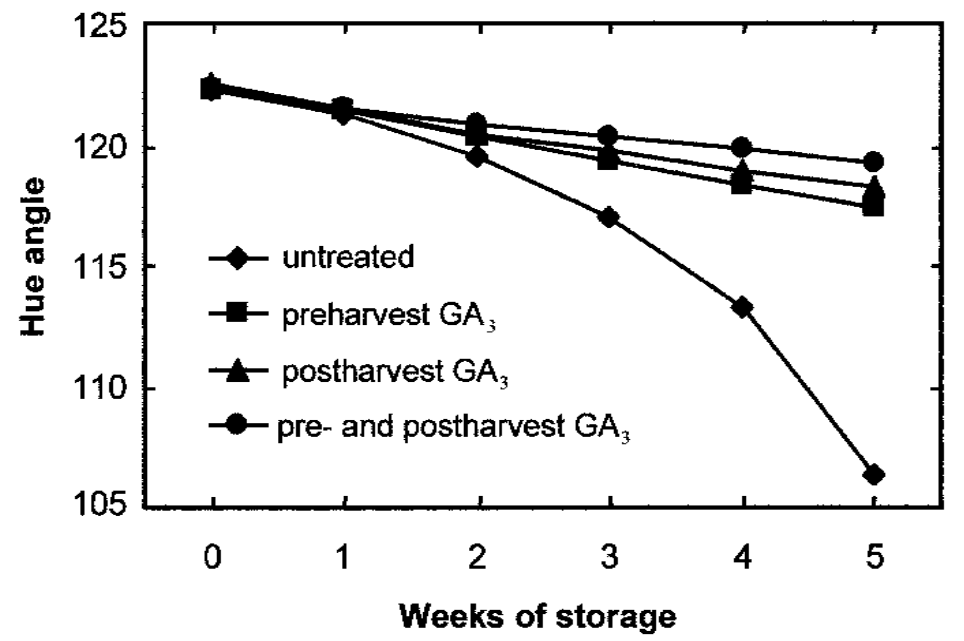

Fig. 2. Effect of gibberellic acid (GA) applications on the degreening of 'Oroblanco' fruit. Fruit were kept untreated, sprayed twice preharvest in the orchard with $10 \mathrm{mg}^{-1}$ of GA, dipped postharvest in $100 \mathrm{mg} \cdot \mathrm{L}^{-}$ ${ }^{1}$ of GA, or sprayed and dipped in GA then stored for 5 weeks at $20^{\circ} \mathrm{C}$. Data are means for 45 fruit from three separate experiments. Green $=120^{\circ}$, yellow $=90^{\circ}$. 
trol at $P<0.01$. The various GA treatments were not significantly different among themselves, however.

Effects of 1-MCP and ethylene on fruit degreening. There was no effect of 1-MCP on the color of 'Oroblanco' fruit (Fig. 3). On the other hand, exposure to exogenous ethylene immediately caused fruit to yellow very slightly, but the accelerated effect lasted no (Fig. 4). A regression analysis of fruit color across time for each concentration of ethylene showed that the various ethylene treatments were significantly different from the untreated control at $P<0.01$. The various ethylene concentrations were not significantly different among themselves, however.

The lack of an effect with 1-MCP and the minimal effect with ethylene could not be attributed to application difficulties, since in the same experiments ethylene markedly increased peduncle abscission, and 1-MCP inhibited this ethylene effect (Table 1). Chlorophyllase activity was higher in green fruit than in already degreened yellow fruit (Table 2); more than 2 weeks after the ethylene treatment however, exogenous ethylene had only a moderate effect (1.7-fold in green fruit and 2.3fold in yellow fruit) on the induction of chlorophyllase activity.

Commercial storage experiments. To evaluate the inhibitory effects of GA and 1MCP on the degreening of these fruit under commercial storage conditions, fruit were stored under temperature regimes that simulated a short quarantine treatment and a longterm storage treatment. The GA treatments alone and the combination of GA plus 1-MCP delayed fruit degreening under both storage regimes (Table 3). However, the further exposure of GA-treated fruit to 1-MCP did not have any additional effect on the loss of green coloration when compared with fruit that were treated only with GA.

During the short quarantine treatment, in which the fruits were held for 3 weeks at $2{ }^{\circ} \mathrm{C}$, the untreated control fruit had degreened only slightly from an initial hue angle of $121.3^{\circ}$. Nevertheless, GA significantly inhibited fruit degreening and the fruit remained completely green (Table 3). After the long-term storage treatment, the untreated control fruit became completely yellow, whereas the GA treatment inhibited the rate of degreening, and the fruit remained greenish-yellow. Apart from the effects of GA on the retention of peel color, neither GA nor 1-MCP had any effect on internal fruit quality characteristics such as TSS and acid content, nor on postharvest storage performance. Differences in weight loss

Table 1. Effect of ethylene and 1-MCP on peduncle abscission in 'Oroblanco' fruit.

\begin{tabular}{lcccc}
\hline & \multicolumn{4}{c}{$\%$ Abscission $^{2}$} \\
& \multicolumn{4}{c}{$1-\mathrm{MCP}\left(\mathrm{nL} \cdot \mathrm{L}^{-1}\right)$} \\
\hline Ethylene & 0 & 20 & 100 & 200 \\
\hline None & $30 \mathrm{a}$ & $10 \mathrm{a}$ & $0 \mathrm{a}$ & $0 \mathrm{a}$ \\
$10 \mu \mathrm{L} \mathrm{L}^{-1}$ & $100 \mathrm{~b}$ & $95 \mathrm{~b}$ & $50 \mathrm{~b}$ & $0 \mathrm{a}$
\end{tabular}

${ }^{2}$ Peduncle abscission was measured after 4 weeks of storage at $20^{\circ} \mathrm{C}$. Data are means of 45 fruit from three experimental replications. Different letters within a column indicate significant differences at $P$ $<0.05$, according to a Student-Newman-Keuls one-way ANOVA test on ranks.

${ }^{y}$ Fruit were exposed for $16 \mathrm{~h}$ to $1-\mathrm{MCP}$, then kept for $3 \mathrm{~d}$ in air or in $10 \mu \mathrm{LL}^{-1}$ ethylene.

Table 2. Effect of ethylene on chlorophyllase activity in green and yellow 'Oroblanco' fruit.

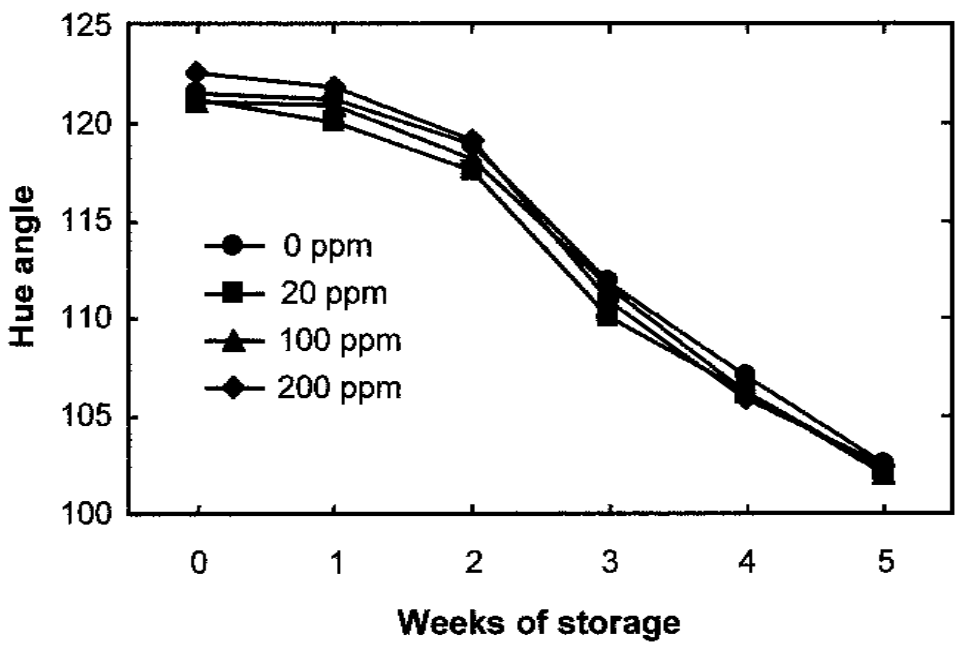

Fig. 3. Effect of 1-methylcyclopropen (1-MCP) on the degreening of 'Oroblanco' fruit. Fruit were kep untreated, or were exposed to 20,100 or $200 \mathrm{nLL}^{-1}$ of 1 -MCP for $16 \mathrm{~h}$ then stored for 5 weeks at $20^{\circ} \mathrm{C}$. Data are means for 45 fruit from three separate experiments. Green $=120^{\circ}$, yellow $=90^{\circ}$.

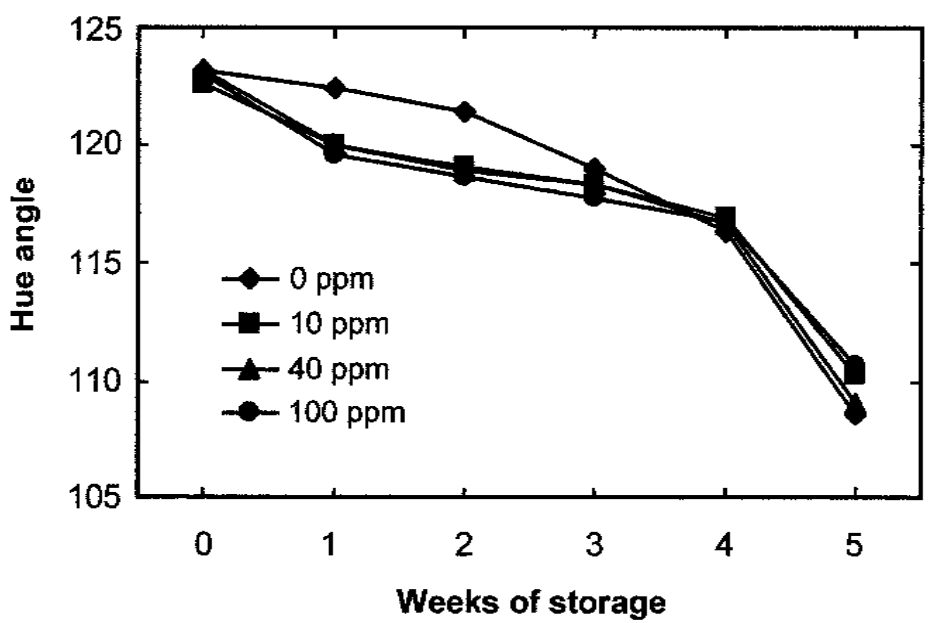

Fig. 4. Effect of ethylene on the degreening of 'Oroblanco' fruit. Fruit were kept untreated, or were exposed to 10,40 , or $100 \mu \mathrm{LL}^{-1}$ of ethylene for $3 \mathrm{~d}$ then stored for 5 weeks at $20^{\circ} \mathrm{C}$. Data are means for 45 fruit from three separate experiments. Green $=120^{\circ}$, yellow $=90^{\circ}$.

\begin{tabular}{llr}
\hline \hline & \multicolumn{2}{c}{$\begin{array}{c}\text { Chlorophyllase activity } \\
\left(\mu \mathrm{M} \text { chlorophyllide } \cdot \mathrm{h}^{-1} \cdot \mathrm{mg}^{-1}\right)\end{array}$} \\
\cline { 2 - 3 } & \multicolumn{2}{c}{ Fruit color } \\
\cline { 2 - 3 } Ethylene $^{\mathrm{y}}$ & Green & Yellow \\
\hline None & $13.64 \mathrm{a}$ & $3.17 \mathrm{a}$ \\
$10 \mu \mathrm{L} \cdot \mathrm{L}^{-1}$ & $23.21 \mathrm{~b}$ & $7.29 \mathrm{~b}$ \\
\hline
\end{tabular}

${ }^{2}$ Data are means of three separate experiments, each of 10 fruit. Green and yellow fruit had hue angles of 118 to $122^{\circ}$ and 100 to $105^{\circ}$, respectively. Different letters within a column indicate significant differences at $P<0.05$, according to a Student-NewmanKeuls one-way ANOVA test on ranks.

${ }^{y}$ Fruits were kept in air or were exposed to $10 \mu \mathrm{L} \cdot \mathrm{L}^{-1}$ ethylene for $3 \mathrm{~d}$.

Table 3. Effect of GA and 1-MCP on quality of 'Oroblanco' fruit following short- and longterm storage.

\begin{tabular}{lcccc}
\hline \hline & $\begin{array}{c}\text { Hue } \\
\text { angle }^{z} \\
\left({ }^{\circ}\right)\end{array}$ & $\begin{array}{c}\text { TSS }^{y} \\
(\%)\end{array}$ & $\begin{array}{c}\text { Acid } \\
(\%)\end{array}$ & $\begin{array}{c}\text { TSS/ } \\
\text { acid } \\
\text { ratio }\end{array}$ \\
Treatment & \multicolumn{4}{c}{ Short storage } \\
Control & $118.1 \mathrm{a}$ & $8.9 \mathrm{a}$ & $0.8 \mathrm{a}$ & $11.1 \mathrm{a}$ \\
GA & $120.6 \mathrm{~b}$ & $8.8 \mathrm{a}$ & $0.8 \mathrm{a}$ & $11.0 \mathrm{a}$ \\
GA + 1-MCP & $120.2 \mathrm{~b}$ & $9.1 \mathrm{a}$ & $0.8 \mathrm{a}$ & $11.4 \mathrm{a}$ \\
& & Long storage \\
Control & $96.9 \mathrm{a}$ & $8.7 \mathrm{a}$ & $0.7 \mathrm{a}$ & $12.4 \mathrm{a}$ \\
GA & $114.1 \mathrm{~b}$ & $8.7 \mathrm{a}$ & $0.7 \mathrm{a}$ & $12.4 \mathrm{a}$ \\
GA + 1-MCP & $111.6 \mathrm{~b}$ & $8.8 \mathrm{a}$ & $0.7 \mathrm{a}$ & $12.6 \mathrm{a}$
\end{tabular}

${ }^{2} \mathrm{Hue}$ angle at harvest was $121.3^{\circ}$; an angle below $115^{\circ}$ is considered unacceptable by the market. Data are means of measurements taken from 100 fruit for each treatment. Different letters within storage columns indicate significant differences at $P<0.05$, according to a Student-Newman-Keuls one-way ANOVA test on ranks.

yTSS $=$ total soluble solids

${ }^{x}$ Fruit were kept untreated, sprayed with $10 \mathrm{mg} \cdot \mathrm{L}^{-1}$ GA in the orchard, or sprayed with GA and after harvest exposed to $200 \mathrm{~nL} \cdot \mathrm{L}^{-1} 1-\mathrm{MCP}$. Afterward, the fruit were stored for 3 weeks at $2{ }^{\circ} \mathrm{C}$ followed by 1 week at $12^{\circ} \mathrm{C}$ and one more week at $20^{\circ} \mathrm{C}$ ("Short storage"), or for 11 weeks at $12{ }^{\circ} \mathrm{C}$ followed by 1 week at $20^{\circ} \mathrm{C}$ ("Long storage"). 
were nonsignificant within storage regimes and averaged $3.5 \%$ and $6.7 \%$ after short- and long-term storage, respectively. There was no decay or chilling injury after either treatment (data not shown).

\section{Discussion}

Low-temperature storage and GA treatments significantly reduced the degreening of 'Oroblanco' fruit. A hue angle below $115^{\circ}$ is unacceptable in the marketplace. To maintain a green-colored fruit with a hue angle above $115^{\circ}$, we suggest as a commercial practice that the fruit should be treated with GA, either as preharvest sprays in the orchard or as postharvest dips, followed by storage at $2{ }^{\circ} \mathrm{C}$. However, since 'Oroblanco' fruit, as well as their grapefruit and pummelo parents, are sensitive to chilling injuries (Chalutz et al., 1985; Waks et al., 1988), the duration of cold storage should not exceed 4 to 5 weeks, which is not sufficiently long to promote chilling damage. Periods of 8 and 12 weeks at $2{ }^{\circ} \mathrm{C}$, however, can cause severe chilling injuries (Chalutz, personal cummunication).

Surprisingly, ethylene had just a slight effect and 1-MCP had no effect at all on the color of 'Oroblanco' fruit. These findings are inconsistent with the well-known behavior of many other citrus cultivars, in which ethylene is commonly used to enhance fruit degreening (Cohen, 1978; Grierson et al., 1986). To the best of our knowledge, the only other case in which ethylene was relatively ineffective in promoting degreening was in regreened 'Valencia' oranges (Eaks, 1977). In that case, ethylene accelerated chlorophyll loss, but at a relatively low rate, so that the visual changes in fruit color were very small (Eaks, 1977). In a similar manner, ethylene had only a relatively small effect on the increase in chloro- phyllase activity in 'Oroblanco' peel: 1.7- to 2.3-fold as compared with an 11.4-fold increase observed in ethylene-treated 'Valencia' oranges (Trebitsh et al., 1993). Therefore, the ethylene treatment of 'Oroblanco' fruit was probably insufficient to promote a remarkable effect on chlorophyllase activity.

\section{Literature Cited}

Ahrens, M.J. and C.R. Barmore. 1986. Interactive effects of temperature and ethylene concentration on postharvest color development in citrus. Acta Hort. 201:21-27.

Chalutz, E., J. Waks, and M. Schiffmann-Nadel. 1985. Comparison of the response of different citrus fruit cultivars to storage temperature. Scientia Hort. 25:271-277.

Coggins, C.W., M.F. Anthony, and R. Fritts, Jr. 1992. The postharvest use of gibberellic acid on lemons. Proc. Intl. Soc. Citricult. 1:478-481.

Cohen, E. 1978. Ethylene concentration and duration of the degreening process in Shamouti orange fruit. J. Hort. Sci. 53:139-142.

Eaks, I.L. 1977. Physiology of degreening-Summary and discussion of related topics. Proc. Intl. Soc. Citricult. 1:223-226.

El-Otmani, M., A.A. M'Barek, and C.W. Coggins. 1990. $\mathrm{GA}_{3}$ and 2,4-D prolong on-tree storage of citrus in Morocco. Scientia Hort. 44:241-249.

Garcia-Luis, A., A. Herrero-Villen, and J.L. Guardiola. 1992. Effects of applications of gibberellic acid on late growth, maturation and pigmentation of the clementine mandarin. Scientia Hort. 49:71-81.

Goldschmidt, E.E., M. Huberman, and R. Goren. 1993. Probing the role of endogenous ethylene in the degreening of citrus fruit with antagonists. Plant Growth Regulat. 12:325-329.

Greenberg, J., S.P. Monselise, E.E. Goldschmidt, and I. Pikner. 1986. Preservation of the distinctive greenish color of 'Sweetie' by gibberellin. Alon Hanotea 41:63-67.

Greenberg, J., Y. Oren, G. Eshel, and E.E. Goldschmidt. 1992. Gibberellin A $\left(\mathrm{GA}_{3}\right)$ on
'Minneola' tangelo: Extension of the harvest season and improvement of fruit quality. Proc. Intl. Soc. Citricult. 1:456-458.

Grierson, W., E. Cohen, and H. Kitagawa. 1986. Degreening, p. 253-274. In: W.F. Wardowski, S. Nagy, W. Grierson (eds.). Fresh citrus fruit. AVI Publ. Co., Westport, Conn.

Jahn, O.L., W.G. Chace, and R.H. Cubbedge. 1973. Degreening response of 'Hamlin' oranges in relation to temperature, ethylene concentration, and fruit maturity. J. Amer. Soc. Hort. Sci. 98:177-181.

Kader, A.A. 1992. Postharvest biology and technology: An overview, p. 15-20. In: A.A. Kader (ed.). Postharvest technology of horticultural crops. Regents of the Univ. of California, Div. of Agr. and Natural Resources, Oakland, Calif.

McDonald, R.E., P.D. Greany, P.E. Shaw, and T.G. McCollum. 1997. Preharvest applications of gibberellic acid delay senescence of Florida grapefruit. J. Hort. Sci. 72:461-468.

McGuire, R.G. 1992. Reporting of objective color measurements. HortScience 27:1254-1255.

Porat, R., B. Weiss, L. Cohen, A. Daus, R. Goren, and S. Droby. 1999. Effects of ethylene and 1methylcyclopropene on the postharvest qualities of 'Shamouti' oranges. Postharvest Biol. Technol. 15:155-163.

Soost, R.K. and J.W. Cameron. 1981. 'Oroblanco', a triploid pummelo-grapefruit hybrid. Proc. Intl. Soc. Citricult. 1:59-60.

Stewart, I. and T.A. Wheaton. 1972. Carotenoids in citrus, their accumulation induced by ethylene. J. Agr. Food Chem. 20:448-449.

Traiber, A., M. Fisher, and A. Rochel. 1984. Seasonal changes in Pomelit fruit during harvest time. Alon Hanotea 38:687-692.

Trebitsh, T., E.E. Goldschmidt, and J. Riov. 1993. Ethylene induces de novo synthesis of chlorophyllase, a chlorophyll degrading enzyme, in Citrus fruit peel. Proc. Natl. Acad. Sci. USA 90:9441-9445.

Waks, J., E. Chalutz, E. Lomaniec, A. Daus, and S. Ben-Yehoshua. 1988. Physiological and pathological observations on the postharvest behaviour of pummelo fruit. Trop. Sci. 28:35-42. 